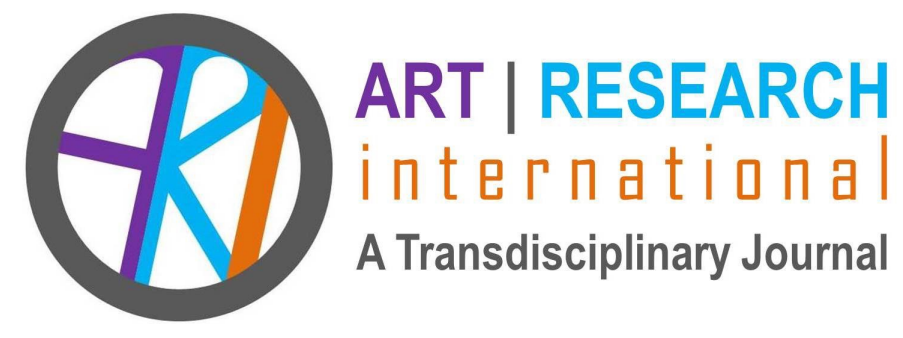

\title{
SPACES IN-BETWEEN: TEXT POEMS FROM COMMUNITY PRACTICE AND RESEARCH
}

\author{
Paula Gerstenbatt \\ University of Southern Maine \\ paula.gerstenblatt@maine.edu \\ Diane McDaniel Rhodes \\ University of Texas at Austin \\ diane.rhodes@utexas.edu \\ Lida Holst \\ University of Southern Maine \\ lida.holst@maine.edu
}

Dr. Paula Gerstenblatt, Assistant Professor at University of Southern Maine, has worked for over 25 years with a focus on macro community practice throughout the United States and West Africa in the non-profit and government sector. As a scholar/artist, she utilizes the arts as a tool for community building, teaching, and research.

Diane McDaniel Rhodes received her Ph.D. in social work from and teaches at the University of Texas at Austin, where her areas of research include partner violence, family violence, and disrupting injustice. She brings twenty-eight years of social service professional experience to her scholarship and teaching, including senior management roles.

Lida Holst, received her MSW from the University of Southern. She is a therapist at a Federally Qualified Health Center in Maine and is passionate about social work practice and qualitative research that highlights individual and community resilience. 
Abstract: A commitment on the part of the academy to address social issues has increased over the past three decades, resulting in service learning courses, volunteering opportunities, and communityuniversity partnerships. Faculty, staff, and community practitioners collaborating to lead these efforts often carry enormous responsibility and answer to often competing interests of students, community members, and universities. Using the experience of an scholar/artist/teacher in a universitycommunity partnership founded by the first author in a racially polarized town, this article explores the potential of arts-based methods, specifically poetry and collage, to mitigate the consequence of this work. The format is a dialogue between two engaged teacher/researcher/practitioners and friends to clarify the hidden experience of the researcher with narrative truth to articulate and share not only experiences, but also lessons learned as a contribution to our fellow teacher/researcher/ practitioners.

Keywords: arts-based methods, community practice, engaged scholarship, collage, poetry 


\author{
TEXT POEM \#1 \\ pulled in a million pieces \\ no matter what i do \\ someone always mad \\ can't sleep \\ or rest \\ holding up \\ carrying \\ center is everywhere \\ but in my center space \\ power-privilege-race \\ personal-eternal-pain \\ dodging my authentic self \\ feeling hung up and out \\ with no where for me \\ to lean into reprieve \\ you are as they say Fucked \\ all kinds of nothing from \\ all kinds of nothing \\ inside me i am one big \\ question mark \\ covering my real face \\ my real hurt \\ my so called anger \\ my emptied out heart \\ unrecorded in real time \\ thrown but not caught \\ and where the hell are you? \\ oh right \\ i forgot \\ again
}




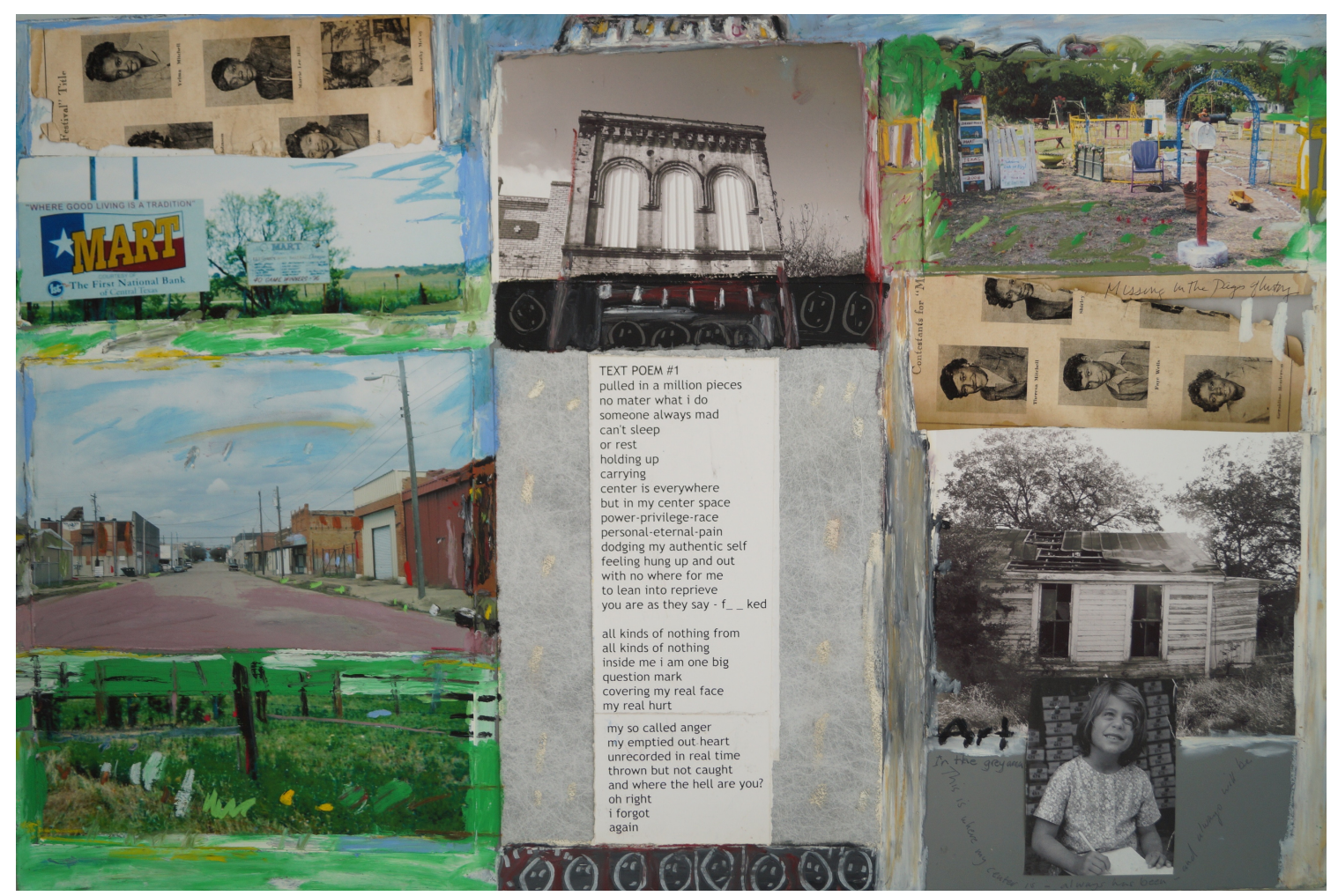

Figure 1. Text Poem \#1

Engaged teaching and scholarship has gained momentum in the past three decades. As a result, there is a commitment on the part of the academy to develop and increase community-university partnerships that address local, regional and even international problems (Campus Compact, 2011). Boyer (1990) championed the responsibility of universities and colleges to shift the paradigm of the publish/perish system of advancement to include "scholarship of engagement" (p. 11) and dedicate resources, including students, faculty and other forms of investment to help tackle "the most pressing social, civic, economic, and moral problems" (p. 11). Boyer's rallying call helped inspire a national resurgence that resulted in a paradigm shift and focus on community engagement beyond the "ivory tower." Examples include a wide array of service learning courses, volunteering opportunities, and the establishment of long and short-term community-university partnerships.

There is a catch though. Faculty involved in engaged teaching and research that is participatory, relational, and community-based often contend with a lack of respect and recognition in the academy advancement process (Ellison \& Eatman, 2008). Most studies on service learning, a common activity of engaged teaching focus on student outcomes (Cress, Burack, Giles, Elkins, \& Stevens, 2010). Less attention has been paid to community partners 
or faculty; however, while scant, there is a body of literature that focuses on the impact and experience of community partners (Cress et al., 2010; Driscoll, Holland, Gelmon, \& Kerrigan, 1996; Gerstenblatt, 2014; Gray et al., 1998; Littlepage, Gazley, \& Bennett, 2012; Maiter, Simich, Jacobson, \& Wise, 2008; Sandy \& Holland, 2006). The consequence of work requiring high levels of interaction with community members to the teacher, researcher, or practitioner has been largely overlooked. Mitigating often conflicting community interests without professional support can be a difficult path to navigate, particularly when dealing with complex social issues. Maintaining a strong exterior on all fronts for the benefit of a project while contending with professional responsibilities can cause duress.

This article addresses the toll of engaged teaching and scholarship using the experience of the first author, Paula Gerstenblatt, in a university-community partnership she founded in a racially polarized town with a significant number of people living in poverty located in the rural South. Two universities were involved, one a large public university and the other a private university. In many ways this essay is a kind of case study, involving the experience of a teacher/researcher/community practitioner engaged in a social justice focused participatory community project and the use of poetry and visual art that both ameliorates and documents the personal cost. In another way, this essay is a dialogue between two engaged teacher/researcher/practitioners and friends as an effort to articulate and share not only experiences, but also lessons learned as a contribution

"Mitigating often conflicting community interests without professional support can be a difficult path to navigate, particularly when dealing with complex social issues." to our fellow teacher/researcher/practitioners. The focus of this essay is to clarify the hidden experience of the researcher with narrative truth underlying the historical facts. We use conversation between the first and second authors, Gerstenblatt and McDaniels, to establish a narrative illuminating the consequence(s) of carrying enormous responsibility, and answering to the multiple and often competing interests of students, community members, and universities. Our third author, Lida Holst, was a graduate student of Dr. Gerstenblatt who contributed her knowledge of secondary and vicarious trauma from her practice and thesis research on social workers working with the homeless. 


\section{Literature}

\section{Trauma, Burnout, and the Impact of Working with High Need Populations}

While there is a gap in literature that addresses the emotional toll and stress of working in high need community settings as an engaged teacher/scholar/practitioner, there is related literature on secondary and vicarious trauma, burnout, and the impact of working with those who have suffered past trauma, as well as working with people who are currently experiencing issues such as homelessness, sexual assault, and other forms of abuse and/or neglect (Bride, 2007; Hesse, 2002; Schauben \& Frazier, 1995). This research can offer helpful insights to gain a deeper understanding of the consequence(s) of being deeply engaged in social justice projects that require a balancing of competing needs and obligations. The complex and difficult problems encountered in communities experiencing racial discord, poverty, and other forms of injustice put enormous pressure on the teacher/ researcher/practitioner to balance multiple roles and responsibilities, while struggling to attend to their feelings of working with people who suffer grave injustice and resulting trauma.

Direct practice work with individuals who have experienced or continue to experience trauma can have adverse psychological effects on practitioners. The terms vicarious trauma, secondary traumatic stress, and burn out, although often used interchangeably, are defined in the literature as three distinct conditions. Vicarious trauma (VT), a concept accredited to McCann and Pearlman (1990) refers to "the transformation that occurs within the therapist (or other trauma worker) as a result of empathic engagement with clients' trauma experiences and their sequelae" (Pearlman \& Mac lan, 1995, p. 558). This "transformation" refers to the adverse changes in practitioners' frame of reference and cognitive change processes that may alter ways of experiencing self, others, and the world (Collins \& Long, 2003; Pearlman \& Mac lan, 1995; Sabin-Farrell \& Turpin, 2003). Like vicarious trauma, secondary traumatic stress (STS) results from exposure and direct practice with clients who have experienced trauma, but the "focal features of STS are the behavioral symptoms that mirror the PTSD presented in the primary victim(s) of trauma, not changes in cognition" (Newell \& MacNeil, 2010, p. 61). Social workers are two times more likely than the general population to develop PTSD due to indirect exposure, independent of any other personally experienced traumas (Bride, 2007). Burnout, a cumulative process overtime, is described as multi-dimensional, with the three core components being emotional exhaustion, depersonalization (cynicism), and inefficacy (reduced personal accomplishment) (Maslach, 2003; Maslach, Schaufeli, \& Leiter, 2001). The single largest risk factor associated with burnout is human service work, due to its high emotional expectations and on-going use of empathy (Maslach \& Florian, 1988; Maslach et al., 2001). Social science research and 
engaged teaching can potentially fall into these categories, though not typically classified that way.

Having an awareness of and utilizing self-care strategies such as supervision, humor, relaxation, exercise, and alternative therapies such as massage and reflexology can help practitioners cope with, alleviate, and prevent burn out, STS, and VT (Collins \& Long, 2003; Newell \& MacNeil, 2010). Many of the same treatments and coping skills utilized by victims of trauma may also translate to those practitioners experiencing STS, including personal psychotherapy (Hesse, 2002). Arts-based therapies can help to clarify the imagery and memory disruptions associated with PTSD, providing an effective method for processing and resolving traumatic imagery (Appleton, 2001). Arts-based tools and therapies may be effective in addressing trauma and emotional upheaval in practitioners.

While the concepts of vicarious trauma, secondary traumatic stress, and burnout have primarily been associated with clinical work, there is a gap in the literature that addresses the emotional duress and trauma of engaged teacher/researcher/practitioners working on social justice focused projects that are deeply embedded in the community. Given the relational and emotional work associated with social justice focused community work, more information is needed on how burnout, STS, and VT affect engaged researcher/ teacher/practitioners who undertake these projects. Additional research is needed on how the same arts-based tools used with communities may be utilized as self-care or therapeutic techniques in alleviating and/or preventing the adverse psychological effects of relational practice with vulnerable or traumatized participants.

\section{Arts-based Methods}

Empirical data and methods do the heavy lifting of informing and measuring. Postmodern, post-colonial, and feminist epistemologies concerned with dislodging authority and elevating oppressed voices have long challenged traditional methods (Leavy, 2009). Artsbased methods, recognized for use in clinical intervention, are powerful tools in analysis and theory building. Visual arts practice, drama, music, and creative writing all have the ability to liberate one from sometimes stifling etiquette and thus give access to meanings and feelings important to understanding. For example, a poem's power to communicate rests with its ability to evoke scene and sense. As a tool in the hands of a researcher, poetry has the potential to juxtapose meanings and facilitate theoretical insight. Spare words in free space carry the weight of essences, even those best expressed with silence (Leavy, 2009). Images also evoke meaning and feelings not available in written transcripts (Gerstenblatt, 2013). In this case, the combination of images and poetry in collage serve to strike at a different emotional and intellectual level. 
Our use of dialogue as a method grew from a shared desire to capture the potential of art as a tool for coping with the sometimes acutely difficult challenges of participatory research and community based social change work. The ability to recognize the ways art works as a coping mechanism, reflective tool, protective factor, and support for self-care has been recognized as a valuable strategy in community art practice, and even in a therapeutic setting (art therapy). This article also posits the possibilities of art methods to be used in a variety of settings, including research, teaching, and practice, to document and recover from the occasional trauma of colliding worlds. The authors engaged in a dialogue about this over the course of several years, and the value of that has been a recognition and acknowledgement that this thing is something - particularly in the face of academia's demands to appear composed and competent while keeping pace with self-advancement. It took a moment for us to realize how poetry embedded in a collage worked, and to understand how the exercise of the expression was critical to us and others facing similar situations. The dialogue and collaboration between us was a significant magnifying glass.

\section{Background}

TEXT POEM \#2

people see me but don't

know where i am

in the abyss of converging realities

compressed

conflicted

to decide if there

is a direction to run in

the old white lady and

her authority-superiority-and how dare you-come here

and think-well anything really

i held my hand and my voice from

smacking her with the truth

and felt i had betrayed a list of people because of it

my kids

my family

my real folks

myself

that took a lot from me

for the project?

what project?

what ever shrinking soul?

i would rather be swallowed by the ground 
than swallow my own voice

with the faces of those i love retreating

into the background of

her one dimensional reality

and soul robbing air I couldn't breath in

much less feel myself

auto-ethnography my ass

this is war

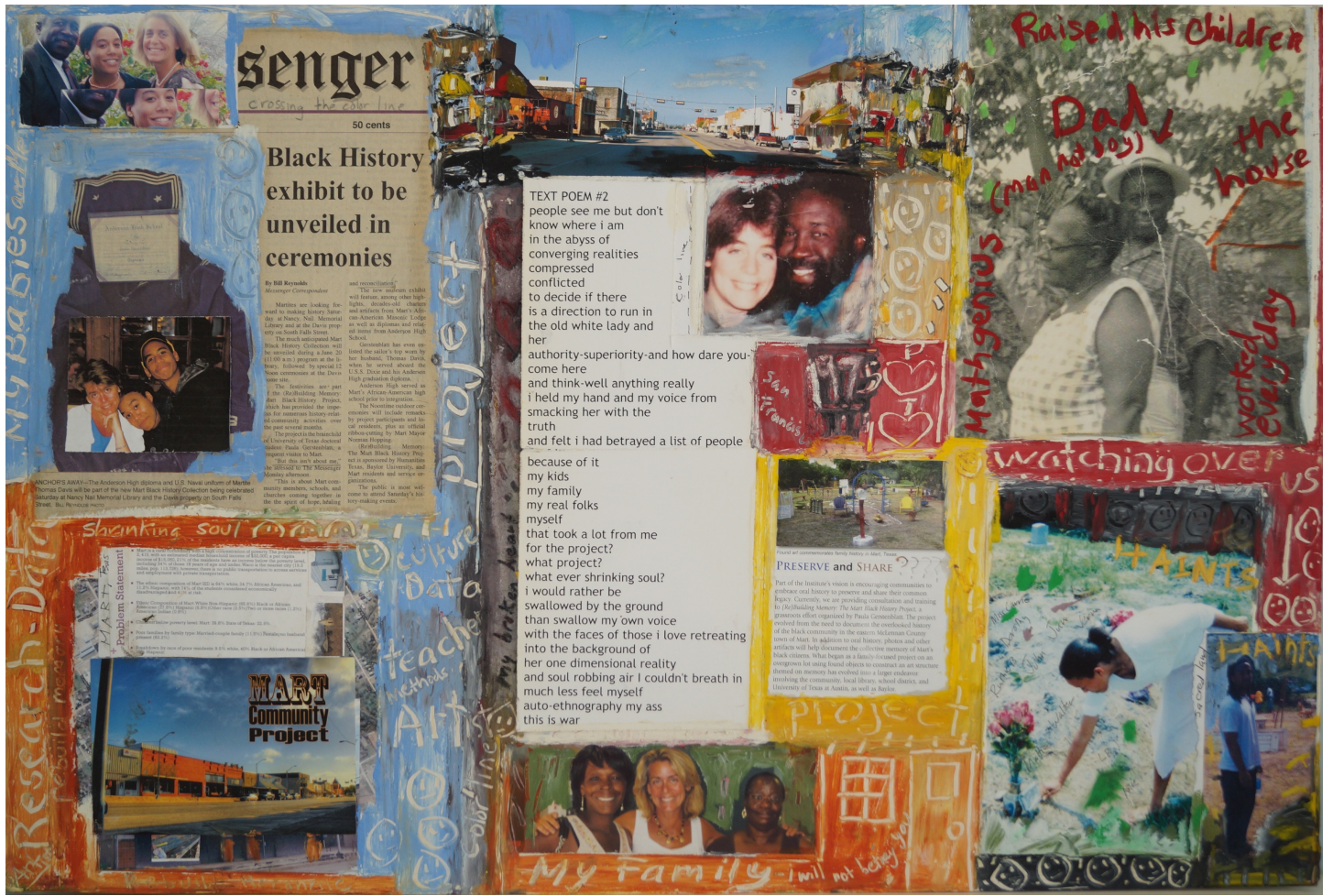

Figure 2. Text Poem \#2

The context of the community-university project was the small rural town in the South. Like many small towns across the American South that once thrived, this town of 2,200 residents experienced a decline in population and economic prosperity when the manufacturing based dissolved and corporate agriculture decimated small farming. Additionally, the legacy of Jim Crow laws, "the codified system of racial apartheid that dominated the American South for three quarters of a century beginning in the 1890s" (PBS, n.d.) continues to manifest in disparities in educational, health, and economic outcomes. In 2008, an art installation built in the African-American neighborhood catalyzed a community engagement initiative between the residents and the two universities. The purpose of this partnership was to use the resources of the university to build local capacity, and identify how arts-based practices and other forms of community development could improve residents' perspectives of their town, 
increase their role in the town's governance, and their ability to have agency in local decision-making processes.

Paula Gerstenblatt, connected to the town through her family by marriage, led the original art installation and founded the community initiative. Over a five-year period, this collaboration created art and design projects supported by a National Endowment for the Arts Your Town and Our Town grants, three state humanities grants, and local foundation funding that resulted in three mosaic murals, a mosaic sculpture, a series of artist and student residencies, and the designation, design, and creation of a community hub at a former football field used during the era of segregation until 2007. During this five-year period, nearly 150 university students and their professors worked side by side with residents, key stakeholders, and artists on community identified issues.

The focus of the work was relational, sought to establish "deep engagement" (Hodgson, 2011; Sandercock, 2004), and build leadership and civic capacity through the ongoing establishment of networks and relationships. The community initiative worked with an "open door" philosophy and reached out to a wide range of residents across generations, race, and economic status, developing a diverse cadre of participants. This method has been referred to as social scaffolding (Stokes, Bar, Baumann, \& Caldwell, 2014) in the way that it helps to ensure a broad spectrum of engagement and sustainability of the efforts. Community members were encouraged to participate as little or as much as they wanted and on any level they were comfortable with, recognizing legitimate peripheral participation (Lave \& Wenger, 1991) that serves an important purpose in building a diverse network and strong relationships. As a result of this practice, students, faculty, and artists were frequent visitors to residents' homes, churches, garage sales, and civic events. This allowed for an intimacy that helped the project flourish, while at the same time opened the door to deep rifts and triggered painful emotions about race, class, and gender. It seemed it was impossible to segment the downside without forsaking the upside; there is no possibility of forming the relationships without encountering the thorny issues associated with this kind of deep engagement. These community-university projects supported a recent civic and political resurgence in the town, which included the election of a new enthusiastic slate of City Council members and the capacity building necessary to receive several new grants towards the improvement of local infrastructure, including a 22 million dollar infrastructure grant. Significantly, the city is now in negotiations with a developer to sell city land to build new housing stock for the first time in over 30 years.

\section{Dialogue}

Paula: Personal Aspects of the Work in Mart. In the summer of 2008, I visited my husband's hometown to construct an art installation themed on memory. My husband grew up during the era of segregation, and felt the painful sting of the Jim Crow South in his daily 
life. However, despite the racism, he told stories that described a strong African American community and a kind of "Huck Finn" boyhood of roaming the woods with friends, excelling in sports, neighborhood characters, and close knit family led by his father who raised his 11 children after his mother's death. We visited the town many times with our own children over the years for family reunions and it was difficult to reconcile his stories of growing up to the contemporary hollowed out town. Abandoned homes, vacant lots, a downtown of empty storefronts, and perhaps most despairing, a still visible color line punctuated by references to "black folks and white folks town." I spent hours with my family as they recited the past during what is sometimes referred to as "porch storytelling." The contrast between what once was and the present compelled me to revisit the possibility that memories could help inspire a renewed effort to make positive change and remind us of the strength that helped sustain this community through difficult times. For me, as an artist and community practitioner, the merger of the two was my strategy to "rebuild" memory and, hopefully, community through an art installation on the vacant lot the family still owned, where the home my father-in-law raised his children once stood.

The transition from family project to community action research was not smooth. Rather, it unfolded through a series of steps inspired by the response of the family and community to the art installation, and a desire the document the overlooked black history of the town. A first humanities grant and the partnership with the oral history department at the private university 18 miles away, as well as a connection with a history professor at the University of Texas at Austin, sparked my desire to move to this area to pursue graduate studies in social work. The collective enthusiasm for the project grew into a dream of revitalizing the community. From class projects and visiting artists to numerous grant acquisitions and dedicated research efforts, the multi-disciplinary community initiative evolved, continuing to reap benefits for the community and university partners.

The work in the town prompted rapidly unfolding events and change processes in the community between, and with, residents, students, and the built environment. I made this choice in accordance with post-modern critical theory and its assumption that "researches are the tools of research and thus construct their findings, which, in turn, allows them to act in two different roles simultaneously" (O’Byrne, 2007, p.1389). Denzin (2006) posits:

Ethnography is not an innocent practice. Our research practices are performative, pedagogical, and political. Through our writing and our talk, we enact the worlds we study. These performances are messy and pedagogical. They instruct our readers about this world and how we see it. The pedagogical is always moral and political; by enacting a way of seeing and being, it challenges, contests, or endorses the official, hegemonic ways of seeing and representing. (p. 422) 
In hindsight, I see the wisdom in Denzin's (2006) perspective. I assisted students in interpreting the phenomena in the town - be it racial, political, or historical. My work there stated a position from which to enact change while striving to engage the community as a whole. We brushed against resistance to change as well as those who embrace it. In the course of one day, students met with community members who, while stating an intention to engage in an act of change, were still reluctant (library commons project) to high school students who approached them, eager to talk and share their visions of change in the town and better yet, offering themselves up to work towards the goal of bettering their community.

There was a constant unfolding of stories and instances that reflected the experiences of residents as they met students they had read about in the local paper; watched our visiting artist from Senegal labor daily on a magical mosaic mural, perhaps taking the step to approach her and add their touch in some way; or sat proudly as they viewed documentaries made by their children during the media camp. Even those who tried to stymie the change slowly gaining momentum in ways big and small were all part of the equation and converging worlds of a vibrant, productive community-university partnership.

\section{The Spaces In-between}

While there is an impressive, larger trajectory to every research project, there are distinct moments in time that elucidate the juxtaposition of multiple roles and the consequence of community embedded work. There are moments when the researcher's perspective collided with those of community members in deeply touching and affecting ways, i.e. a study of bulimia by two researchers who have recovered from eating disorders, or the study of cancer treatments by a researcher who has had cancer (Hildebrandt \& Voeller, 2014). When embroiled in community-based research, the notion of consequence can be unattended in favor of the pressing needs of residents, students, institutions, and other participants.

In the situation discussed in this article, the potency of racism, coupled with classism and poverty, brought about internal personal conflict while trying to maintain responsibility for the project and an exterior manner that conveyed optimism, competency, fair mindedness, and professionalism as a teacher, researcher, doctoral student, and manager of all grant awards. In any community action research endeavor there are proposing phases, planning phases, preparation and engagement phases, and action phases. Unspoken are the spaces in-between where the simple unexpected turn of a conversation, an observation, or an outcome wrenches at the heart and mind and the researcher is compelled to absorb and manage something deeply personal. 


\section{In-between Spaces: One}

Paula. While spending a few days in the town, I met with the local "pioneer family" matriarch who was resistant to the community initiative. Like me, she married into her "town family." Unlike me, her husband's family was prosperous, prominent, and white. They controlled quite a bit of land holdings, in the area and beyond. She was irritated by the fact that our project was funded over her favored project by a local foundation. I went to visit her in the spirit of community building and, to be honest, to appease some of our older, white supporters who viewed her as a potential asset or threat.

On the surface, the meeting went well enough - she basically interrogated me with questions about the project, including asking how much we were paying artists, how many people were involved, and were we working with a "select" group of people (code for black people). I responded with the same transparency evident at our meetings where a budget was available for everyone to review. I was polite, I suppressed my authentic self in the "best interests" of the project, and when the moment came to leave, I exhaled. There was personal chitchat about our lives and children. We were a well-traveled, well-educated, family. Her usual superior attitude did not impress me; however, her reference to certain members of my extended family made me want to scream. I knew better. I knew my niecein-law's mother was not her "good friend who helped her raise her children" - she was her maid. I sat and listened though, I did not challenge her construction of reality, nor did I express sarcasm or outrage when she said she did not care about the class of university students coming in the fall and spring semesters to work on service projects. Of course not, her agenda was driven by her favored project not receiving funding because, in her mind, ours had displaced her previously unchallenged annual allocation.

\section{In-between Spaces: Two}

Paula. During this same period I encountered a class/race battle with an artist, a member of my team. She was from a nearby town, very talented and bright, and has endured her own battle coming from an established white family as an artist who has walked a different path. However, the collision of class and race in the town provoked a confrontation between us on the goals of the project, what community building is, and how best to achieve "outcomes." I felt beat up - accused of being anti-white, extreme, socialist, and having a chaotic work style. I was overwhelmed and for the first time in two years I wondered why I pursued this unwieldy project to begin with in the class entrenched, racially polarized south. Being the over responsible person that I am, and leader of the project with many folks depending on my enthusiasm, vision, and energy, I sucked it up and do what I always do - kept moving with my pain and doubt in tow. 
Time for process and reflection was hard to come by in the heart of the project's action phase. Still, I was experiencing trauma. I found myself sobbing and unable to sleep at night. I put on my game face, trying to reconcile all the opposing forces and endure the notso-subtle racial statements and the frustration I was feeling towards both sides of the color line for different reasons. The pressure was building and I could not contain it. I missed my house, about an hour and half away in the city where the public university is located, and my two Golden Retrievers who offered less complicated companionship. Knight and Schwarzman (2006) caution against over investment in the end result while short-changing the process of learning and social change. I was suffering from this very misstep, and a neglect of the auto-ethnographic and reflective process.

I was compelled to consider the consequence of community building, activist scholarship, and working in a place where the authentic self is sometimes shrouded. I felt as if I had betrayed my biracial children, my family, and members of the community who had been given short shrift for generations. And for what? Was this really the way to go? And at what price for everyone involved, including me? I found myself sobbing in the parking lot at Wal-Mart. When my niece called me, she heard the quiver in my voice and rushed over to comfort me, assuring me I had betrayed no one. The outrage and hurt I was feeling was nothing new to her, or the rest of my family, including my kids who grew up dealing with racism everyday in a so called progressive area on the West Coast. "Keep doing what you are doing," she insisted, "It matters and will reap us all benefits."

My colleague in the project and friend, an oral historian at the private university, urged me to record everything. He put his arm around me and told me I never had to meet with that woman again or answer her questions. The tears streamed down my face, finally feeling I could reveal my true self and lean into someone without risking the project. Although I knew I had to begin my own account, I had little concentration for writing while spending my days like a whirling dervish between tasks. I also knew if I started writing on the computer it would get bogged down with intellectual masking tape and forsake the gut wrenching rawness of my feelings. One early morning when sleep was elusive, I began a series of what I would come to call "text poetry," using my phone, a rather intimate device, texting in my bed and then moving outside to the porch when the sun began to rise.

\section{TEXT POEM \#3}

you won't read this

rendering my words null and void

so why not yell at the top of my lungs?

i give up

and out

of here

the rage of it all 
stepped over the color

line without my colors

true colors

that is a mosaic no one wants to see

too much red

all that blood, Blood (no pun intended)

now which history do you mean to represent?

safe or sorry?

both and neither

we are repackaging our souls

bending over backwards

trying not to break

but we have already broken

good thing you and no one will read this

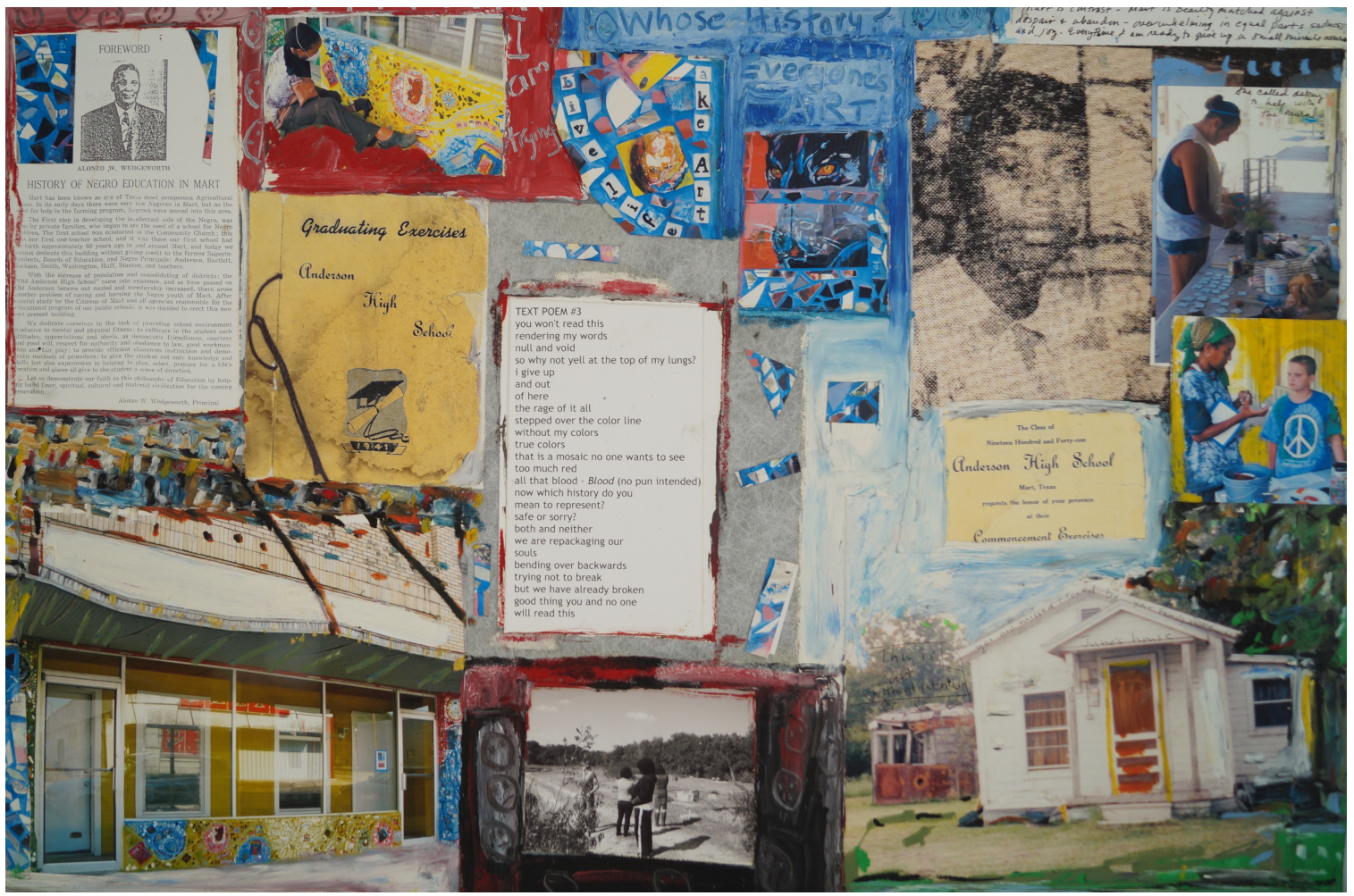

Figure 3. Text Poem \#3

\section{In-between Spaces: Three}

Diane. On a sunny, cold Maine morning, I sat down with the Paula to talk about the text poems. Our relationship as co-researchers flows from our meeting in graduate school, helping one another survive school and family through friendship over the course of many 
years. To take several steps back from my assumptions - having been part of the Paula's life at the time - it was valuable to interview her about what was at the root of the poems from her time in the town. I have been to the town and was fortunate to watch and listen as the various aspects of the project took flight. I heard first hand from residents that the work of the community initiative changed not just how they saw their town but caused them to take up responsibility for it. I was more than peripherally aware how exhausting the project was for several of my colleagues. Our history of dialogue as we work and research spurred the idea of using a formal interview as part of gathering and organizing our thoughts while writing. Interviewing each other can ignite a lot of possibilities for forming theory.

Sitting in the living room, the first thing I wanted Paula to tell me was explicitly where the poems came from. In the midst of intense pain and overwhelm, unable to sleep, she said, "I was at loss for some other kind of response. I felt so much emotion and yet I felt I had to maintain my armor... because I had so many people coming to me, and so many people I was responsible for. So in some ways, I think there was no place for me to go with it, that it was like an act of desperation, I guess."

Paula reflected that she probably wrote her first poetry when she was ten or eleven years old. She described having "written poetry at times in my life where there is a certain degree of upheaval. I have always incorporated words into my visual pieces, collages, and windows. Something that wasn't foreign to me, but it's not my first line of rapport as an artist. When I started writing them I didn't think 'oh, I'm sitting down writing poetry' but when I sat down it's like a natural reflex. Even though I hadn't done it in awhile, there it was."

When she reads the poems today, she "can step back into what those feelings were and what I was dealing with at that time." Looking back she felt the process of writing the poems that night helped her attend to herself in a way that she could not do publicly. "Even a conversation like that [with a friend] might not have allowed me to connect with those feelings and be able to articulate them in the same way. And I think art accesses things and allows them to come up. It allowed me to go to the most raw spot and be able to express what was going on inside me."

As she reflected aloud about what was a mostly interior process, it seemed that the acts of tenaciously supporting the project and those involved, the responsibility to ensure the interventions and the research moved forward served to isolate any personal impact the work generated. I asked her to speak to what might have happened if she had not written something. Caught between a rock and hard place, she said, "I could not contain my authenticity in who I was, it would have been far more damaging to me, I don't know how I would've squelched it." 
In the wake of texting over a period of time, the words "connected my being there with everything that had happened" not just in the present, but in the past, through her ever evolving relationships with the people and with the place. The writing, without the need for grammar or punctuation, without the filter of scholarship, without another person's eyes, allowed her to touch and contextualize the experiences. "Going into the zone that has a piece of creativity in it allows you to enter into spaces that are not always accessible" when caught in the pragmatic business of accomplishment. "The writing allowed me to see this wasn't just a one dimensional experience" of a dilapidated segregated community, but rather a complex story that intersected with personal pasts and relationships. The mythology of the town's history had touched an urge as a social worker and as an artist to see something happen there. While the text poems served a powerful function of healing and recontextualizing the trauma caused by the work, they were also stark evidence of the humanity and fragility of people trying to engage one another.

"When I wrote [the poems], I thought they had to be hidden, because they were so raw and personal and disclosed a part of the work that represented things I felt I could never put voice to - would risk the project, would risk my scholarly standing, not something I could really share." The text poems were words coming out of a crisis of practice. Months later, as part of another project, Paula was encouraged to create collages using the text poems as a form for analyzing the poetry (Gerstenblatt, 2013). "By the time I started doing the collages, I could show the poems to someone. I could not take them into the town and post them on the main street, but could possibly show them to colleagues." The collages provided visual dimension for the poems, weaving in the subtexts of history and a bit of the mythology of the town, grounding the emotions and immediacy of the words. The collage work was part of a planned process that served both as a vehicle for working with the poems and raising them into public life. The process of going through pictures while building the collages was a potent reminder of the joy experienced in the project and an opportunity to see the work holistically. The medium of collage, which included the poems and images, was an apt metaphor for what often felt like a collision between competing interests and responsibilities. The visual aspect of collage worked to include a display element accessible to a larger audience and enabled conversations that might not happen if an individual is reading a poem. The five text poem collages, as a body of work, expand the notion of what constitutes poetry, as well as possibilities for expression.

Reflecting on the process is a reminder of what the experience was, how important it was to have another means of articulating it. It's also a way of understanding and sharing the experience at a very human level. Presenting the process as an option for others. As a professor or as a scholar there is an armor we feel obligated to hold up and we don't have ways to let those cracks appear. Others find good value in discovering new avenues to pursue for their own self care or with clients they are working with. This might be something that people can lean on - not in the lens of 
producing formal art - but within the purpose of reflection, insight, and learning" (Paula Gerstenblatt, personal communication, January 12, 2016).

\section{TEXT POEM \#4}

you wonder where i am

no where

and everywhere

crossing borders

retreating

this is my artistic body of

no work

we are breaking ground

and plates-tiles-oh yeah

and minds

community engagement

through art

visions

research

truth and lies

bad asses

aristocrats

crack heads

faith based with no faith

this is my artistic body of no work

cause work equals truth

or dare

and right now i am

neither 


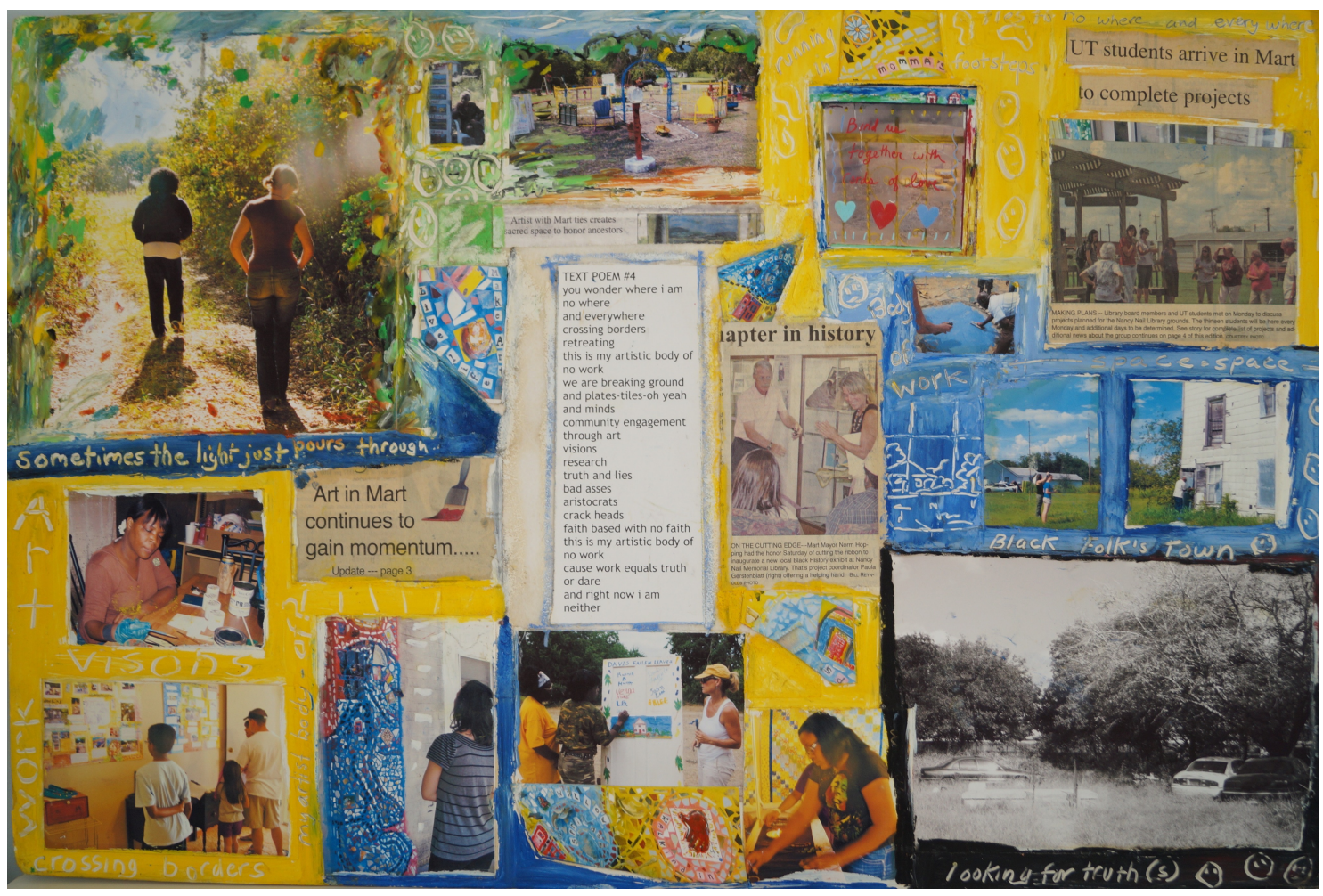

Figure 4. Text Poem \#4

\section{Conclusion}

There is a humanistic big picture to engaged teaching, research, and relational participatory community practice containing both the sublime and the ridiculous, yet often overlooked. Alongside the pragmatic costs of travel, supplies, and time, lay the costs of sadness, joy, risk, suspense, and energy. Using one's knowledge and expertise to build new knowledge and grow community is thirsty work. The tangible rewards of a research endeavor are not necessarily reciprocal to the personal energy required to see the work through.

Engaged teachers, scholars, and practitioners are explicitly honor bound to bring their knowledge, experience, resources, skills, and time measured pedagogies and methodologies to address complex issues and problems. They are also implicitly bound to find the tools necessary to survive the work they do, offer a meaningful learning experience to students, bracket biases to the side, while sustaining both the project and themselves. Applying meaning through words and images through artwork is one strategy for surviving emotionally taxing work. Individuals' interactions with art, as creators or engaging with someone else's, are often an attempt at creating and sharing meaning. 
It is critical for us as teachers and scholars to apply methodology to our survival efforts with the same kind of rigor with which we tackle data collection and analysis. These reflections can also be used as teaching tools to expand student understanding of reflexivity as a form of rigor in qualitative research methods, and as a way to attend to the conflicts they will face in their scholarship. Locating and using reliable methodology for looking back at experience and measuring the personal toll gives us windows into improving at our profession, honing our skills, preserving our longevity. We do tend to author our own stories in our research, sometimes through the voices of others. Autoethnographic tactics and artsbased methods provide us with avenues for thinking within our own story, allowing narrative ethics to guide the practice of reflexive self-management. Art provides accessible and touching documentation of those reflexive moments (Frank, 2013).

This is one narrative shared in the recognition that the problems remain complex without obvious fixes. Social scientists will continue conducting research in communitybased settings, grappling with difficult social issues. Therefore, future research measuring the impact of such work on the researchers and describing the personal costs is needed. Are they suffering? What strategies are used and are they successful? What are those experiences like for researchers? Is there institutional support, reward, or recognition of the value of community-based work? As these questions are explored it is hoped that new data will shed light on the personal costs experienced in the necessary pursuit of engagement with disenfranchised and often silenced communities who disproportionately bear the brunt of our social problems. We also hope that useful strategies will emerge alongside arts-based efforts to ameliorate the negative effects of such intense work.

TEXT POEM \#5

i am on the stoop

on a street in black folks' town

white woman in pajamas

early before the heat chokes me

alone but for the stray dogs wandering around

looking for? not me

this is the street where

tommy lived

played up and down

before everything happened

that led him to

me

and rena

and jonathan

how do you wrap your arms around magic?

time and space? 


\author{
i want to see him back then \\ floating free and happy in \\ his childhood \\ on a street of carefully \\ tended homes \\ and gardens \\ occupied by caring people \\ not this collection of \\ dilapidated and defeated \\ and abandoned and overgrown \\ why can't i see him \\ instead of this? \\ i sure don't have a problem seeing \\ past/present racial divide \\ boy stay in your place- \\ this nice place we made \\ for you to keep you away from us place \\ oh but look, there is a \\ red robin fluttering
}

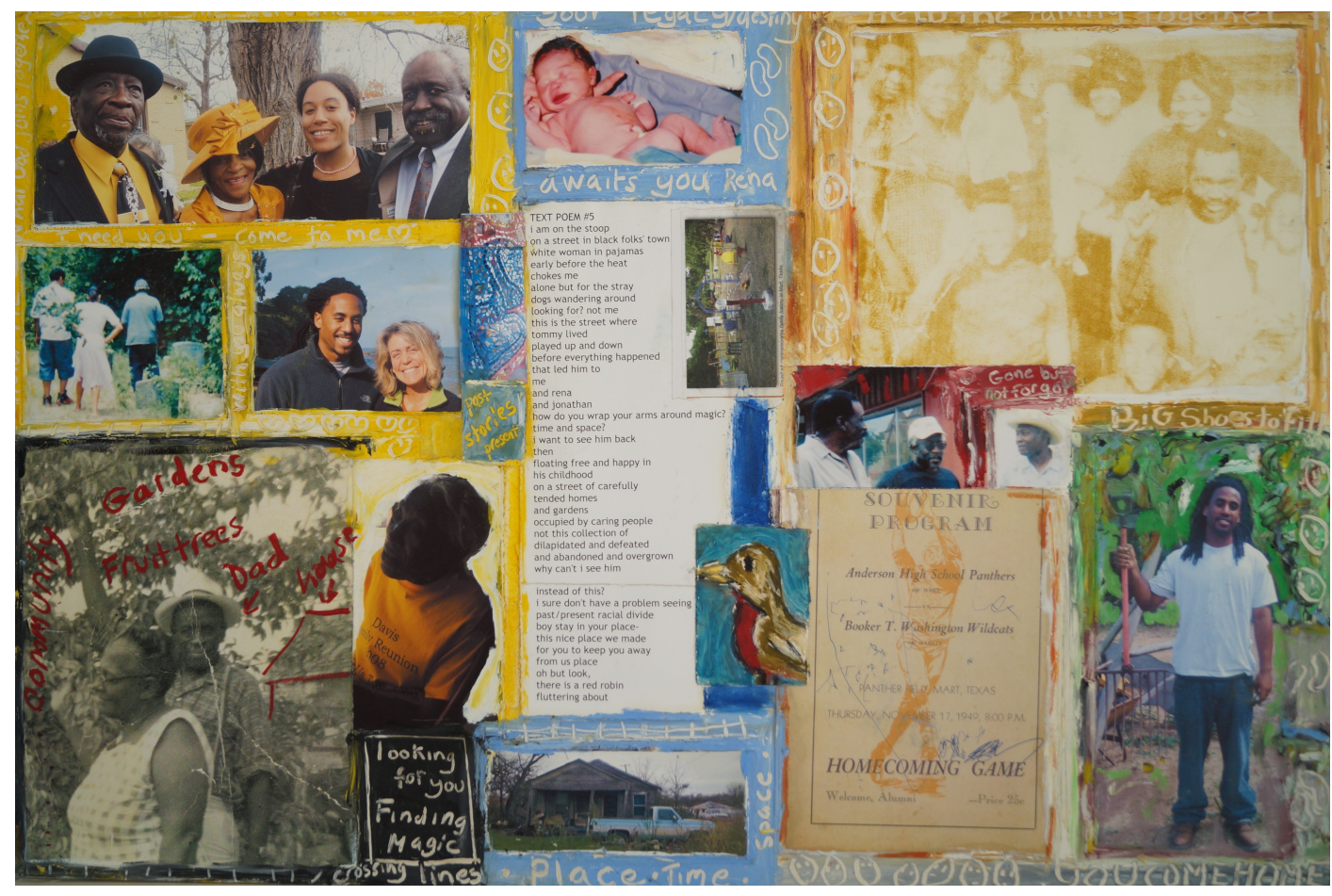

Figure 5. Text Poem \#5 


\section{REFERENCES}

Appleton, V. (2001). Avenues of hope: Art therapy and the resolution of trauma. Art Therapy: Journal of the American Art Therapy Association, 18(1), 6-13.

Bride, B.E. (2007). Prevalence of secondary traumatic stress among social workers. Social Work, 52(1), 63-70.

Boyer, E. L. (1990). Scholarship reconsidered: Priorities of the professoriate. New York, NY: Jossey-Bass.

Campus Compact (2011). Annual member survey results: Executive summary. Boston, MA: Campus Compact.

Collins, S. \& Long, A. (2003). Too tired to care? The psychological effects of working with trauma. Journal of Psychiatric and Mental Heath Nursing, 10(1), 17-27.

Cress, C. M., Burack, C., Giles, Jr., D. E., Elkins, J., \& Stevens, M. C. (2010). A promising connection: Increasing college access and success through civic engagement. Boston, MA: Campus Compact.

Denzin, N. K. (2006). Analytic autoethnography, or déjà vu all over again. Journal of Contemporary Ethnography, 35(4), 419-428.

Driscoll, A., Holland, B., Gelmon, S., \& Kerrigan, S. (1996). An assessment model for service-learning: Comprehensive case studies of impact on faculty, students, community, and institutions. Michigan Journal of Community Service Learning, 3(1), 66-71.

Ellison, J., \& T. K. Eatman. (2008). Scholarship in public: Knowledge creation and tenure policy in the engaged university. Syracuse, NY: Imagining America.

Frank, A. W. (2013). The wounded storyteller: Body, illness, and ethics ( $2^{\text {nd }}$ ed.). Chicago, IL: University of Chicago Press.

Gerstenblatt, P. (2014). Community as agency: Community partner experiences with service learning. Journal of Community Engagement, 7(2).

Gerstenblatt, P., (2013). Collage portraits as a method of analysis in qualitative research. International Journal of Qualitative Methods, 12(1), 295-309. 
Gray, M. J., Ondaatje, E. H., Fricker, R., Campbell, N., Rosenblatt, K., Geschwind, S., Goldman, C. A., Kaganoff, T., Robyn, A., Sundt, M., Vogelgesang, L., \& Klein, S. P. (1998). Coupling service and learning in higher education: The final report of the evaluation of the Learn and Serve America, Higher Education Program. Santa Monica, CA: The RAND Corporation.

Hesse, A. (2002). Secondary trauma: How working with trauma survivors affects therapists. Clinical Social Work Journal, 30(3), 293-311.

Hildebrandt, M. \& Voeller, M. (2014). Thinking with art, or what happens when a critic sees you lose your hair. Departures in Critical Qualitative Research, 3(2), 117-143.

Hodgson, K. (2011). Community heritage and culture: How the arts and cultural sector strengthen cultural values and preserve heritage and history. Arts and Culture Briefing Papers 02. Chicago, IL: American Planning Association.

Knight, K., \& Schwarzman, M. (2006). Beginner's guide to community-based arts. Oakland, CA: New Village Press.

Lave, J., \& Wenger, E. (1991). Situated learning: Legitimate peripheral participation. Boston, MA: Cambridge University Press.

Leavy, P. (2009). Method meets art: Arts-Based research practice. New York, NY: The Guilford Press.

Littlepage, L., Gazley, B., \& Bennett, T.A. (2012). Service learning from the supply side: Community capacity to engage students. Nonprofit Management and Leadership, 22(3), 305-320.

Maslach, C. (2003). Job burnout: New directions in research and intervention. Current Directions in Psychological Science, 12(5), 189-192.

Maslach, C., \& Florian, V. (1988). Burnout, job setting, and self-evaluation among rehabilitation counselors. Rehabilitation Psychology, 33(2), 85-93.

Maslach, C., Schaufeli, W. B., \& Leiter, M. P. (2001). Job burnout. Annual Review of Psychology, 52(1), 397-423. 
Maiter, S., Simich, L., Jacobson, N., \& Wise, J. (2008). Reciprocity: An ethic for community-based participatory action research. Action Research, 6(\#), 305-325.

McCann, L., \& Pearlman, L. A. (1990). Vicarious traumatization: A framework for understanding the psychological effects of working with victims. Journal of Traumatic Stress, 3(1), 131-149.

Newell, J.M., \& MacNeil, G.A. (2010). Professional burnout, vicarious trauma, secondary traumatic stress, and compassion fatigue: A review of theoretical terms, risk factors, and preventative methods for clinicians and researchers. Best Practices in Mental Health, 6(2), 57-68.

O'Byrne, P. (2007). The advantages and disadvantages of mixing methods: An analysis of combining traditional and autoethnographic approaches. Qualitative Health Research, 17(10), 1381-1391.

Public Broadcasting Service. (n.d.). Jim Crow Laws. Retrieved January 9, 2018, from http://www.pbs.org/wgbh/americanexperience/features/freedom-riders-jimcrow-laws/

Pearlman, L. A., \& Maclan, P. S. (1995). Vicarious traumatization: An empirical study of the effects of trauma work on trauma therapists. Journal of Psychology: Research and Practice, 26(6), 558-565.

Sabin-Farrell, R., \& Turpin, G. (2003). Vicarious traumatization: Implications for the mental health of health workers?. Clinical Psychology Review, 23(3), 449-480.

Sandy, M., \& Holland, B. A. (2006). Different worlds and common ground:

Community partner perspectives on campus-community partnerships.

Michigan Journal of Community Service Learning, 13(1), 30-43.

Sandercock, L. (2004). Towards a planning imagination for the 21st century. Journal of the American Planning Association, 70(2), 133-141.

Schauben, L. J., \& Frazier, P. A. (1995). Vicarious trauma: The effects of female counselors working with sexual violence survivors. Psychology of Women Quarterly, 19(1), 49-64.

Stokes, B., Bar, F., Baumann, K., \& Caldwell, B. (2014). Neighborhood planning of technology: Physical meets digital city from the bottom-up with aging payphones. The Journal of Community Informatics, 10(3). 